\title{
GYÓGYSZERMARADVÁNYOK FELSZÍNI VIZEKBEN
}

\section{PHARMACEUTICAL RESIDUES IN SURFACE WATER}

\author{
Záray Gyula \\ DSc, professor emeritus, Eötvös Loránd Tudományegyetem, MTA Ökológiai Kutatóközpont Duna-kutató Intézet \\ zaray@chem.elte.hu
}

\section{ÖSSZEFOGLALÁS}

Különböző gyógyszerek és azok metabolitjai eltávolítását a szennyvíztisztító üzemekben általánosan alkalmazott mikrobiológiai tisztítási fokozat nem vagy csak részben biztosítja. Mivel ezen kis koncentrációban jelen lévő szerves mikroszennyezők együttes és hosszú távú hatása nem ismert, törekedni kell a szennyvíztisztítás hatásfokának javítására, mind a parti szűrésen alapuló ivóvízellátás, mind a vízi ökológiai rendszer egyensúlyának megóvása érdekében.

\section{ABSTRACT}

Pharmaceuticals and their metabolites cannot be or can only partially be removed by microbiological processes in wastewater treatment plants. Since the combined and long-term effect of these organic micropollutants is unknown, it is necessary to improve the efficiency of wastewater treatment in order to ensure safe drinking water supply based on bank filtration and to protect the balance of the aquatic ecosystem.

Kulcsszavak: gyógyszermaradványok, felszíni vizek, vízminőség

Keywords: pharmaceutical residues, surface water, water quality

Istvánovits Vera 2015-ben a Magyar Tudományban értékelte a felszíni vizek kutatásának hazai helyzetét, és tett javaslatokat ezen interdiszciplináris kutatási terület fejlesztése érdekében (Istvánovits, 2015). Lovász László, az MTA elnöke a tudós testület 187. közgyúlésén 2016 májusában jelentette be a Nemzeti Víztudományi Program létrehozását. További előrelépést jelentett, hogy a kormány intézkedési tervet (1110/2017. [III.7.]) fogadott el a Nemzeti Vízstratégia végrehajtásáról. Alapvető változás a korábbi irányelvekhez képest, hogy a vészhelyzet elhárítására összpontosító vízkárelhárítás helyett a megelőző vízgazdálkodást helyezték előtérbe, ugyanakkor fontos cél a vizek ökológiai és vízminőségi álla- 
potának fokozatos javítása, a jó állapot elérése, és a vízfolyások természetes állapotának megtartása. Ezen feladatok megoldásának természetesen harmonizálni kell az Európai Unió idevonatkozó irányelveivel és határozataival.

A felszíni vizek kémiai állapotát befolyásoló szennyezők vonatkozásában az Európai Parlament és Tanács 2455/2001/EU sz. határozatában rögzítették a vízpolitika területére vonatkozó elsőbbségi anyagok jegyzékét, amely a 2000/60/EK irányelv $\mathrm{X}$. mellékletévé vált. Ebben harminchárom vegyületet, illetve vegyületcsoportot neveztek meg, amelyek perzisztens, bioakkumulatív és toxikus tulajdonságokkal rendelkeznek. A fent nevezett irányelv 2013 augusztusában tett módosítása során határozat született egy megfigyelési lista létrehozásáról, amelyre három gyógyszerhatóanyag (diklofenák, 17- $\beta$-ösztradiol és 17- $\alpha$-etinilösztradiol) is felkerült annak érdekében, hogy monitoring adatokat lehessen gyüjteni ezen anyagok által jelentett veszélyek kezelését, illetve elhárítását célzó intézkedések meghozatalára.

A gyógyszermaradványok sorsának a szennyvíztől a felszíni vizeken át az ivóvízig terjedő, átfogó vizsgálatát célzó kutatások már a 90-es években megkezdődtek a világ számos országában. A kutatói érdeklődést jelentősen megnövelte az a tény, hogy ivóvizekben is ng/L koncentrációban mutattak ki különbözö gyógyszermaradványokat (Jones et al., 2005). Ezen vizsgálatok szerinti igényt a fent említett EU-rendeletek még tovább növelték. Számos kutatócsoport közölt cikkeket a szennyvizekben, felszíni vizekben, valamint ivóvizekben lévő gyógyszermaradványok vizsgálatát célzó analitikai kémiai módszerfejlesztésekről és ezen mikroszennyezők eltávolítását célzó technológiák kidolgozásáról. Jellemző példaként a megfigyelési listán szereplő diklofenákkal kapcsolatos, különböző környezettudományi folyóiratokban közölt publikációk számának alakulását szemlélteti az 1. ábra.

Megemlítendő továbbá, hogy Klaus Kümmerer szerkesztésében már 2001-ben megjelent az első könyv, majd ezt követően több bővített kiadása, amelyekben a szerzők a humán és az állatgyógyászatban alkalmazott gyógyszerek maradványainak a környezetünkben való előfordulását, sorsát és a vízi ökológiai rendszerre gyakorolt hatását igyekeztek megvilágítani (Kümmerer, 2001).

Hazánkban az Eötvös Loránd Tudományegyetem Környezettudományi Kooperációs Kutató Központjában (ELTE KKKK) 2006-ban kezdődtek meg a jelentős mennyiségben használt nemszteroid bázisú fájdalomcsillapító és gyulladásgátló gyógyszerek (diklofenák, ibuprofen, ketoprofen és naproxen) vízmátrixból történő kimutatását és mennyiségi meghatározását lehetővé tevő analitikai kémiai módszerfejlesztések. Ezen munkák során a négy hatóanyagnak a vízmátrixból történő elválasztását és dúsítását valósították meg szilárdfázisú extrakció (SPE) alkalmazásával, majd származékképzést követően gázkromatográf-tömegspektrométer (GC-MS/MS) rendszerrel történt a célvegyületek mennyiségi meghatározása az Észak-pesti Szennyvíztisztító be- és kifolyóinál, valamint a Dunából vett 


\section{Diklofenák}

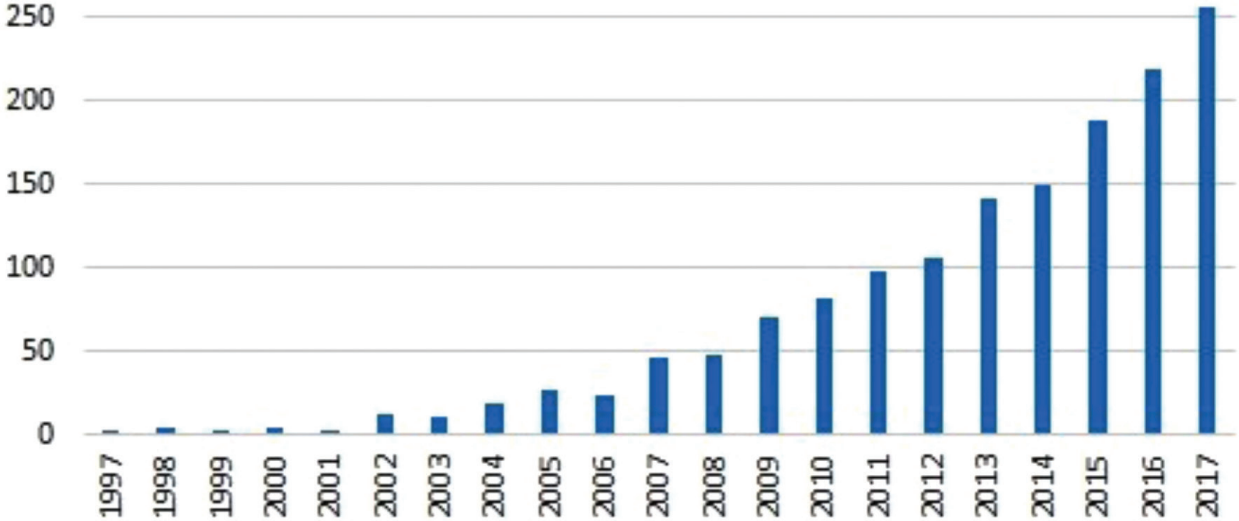

1. ábra. Környezettudományi folyóiratokban megjelent, diklofenákkal foglalkozó publikációk számának alakulása (1997-2017)

vízmintákban (Sebők et al., 2008, 2009). Megállapítást nyert, hogy a fent nevezett gyógyszerek a világ más nagyvárosaiban müködö háromfokozatú (mechanikai szürés, biológiai lebontás és kémiai kezelés) szennyvíztisztítókhoz hasonlóan a befolyóknál $\mu \mathrm{g} / \mathrm{L}$ koncentrációban fordulnak elő, és eltávolításuk a kifolyóknál mért adatok alapján 5-90\% hatásfokkal jellemezhetö. Ugyanis a biológiai fokozatban alkalmazott eleveniszapos technológia jó hatásfokkal biztosítja a nitrogén és a foszfor eltávolítását, de a gyógyszermaradványokról ez nem mondható el. A biodegradációért felelős mikroorganizmusok enzimkészlete elsődlegesen a természetes molekulák lebontására adaptálódott. Új, mesterséges molekulák degradációjához a baktériumok adaptációs időt igényelnek. A gyógyszermaradványok oldaláról viszont hangsúlyozni kell, hogy a biodegradációt különböző xenofor csoportok, (például: - $\mathrm{Cl},-\mathrm{Br},-\mathrm{NO}_{2},-\mathrm{SO}_{3} \mathrm{H},-\mathrm{CN},-\mathrm{CF}_{3}$ ) gátolják, sőt ezen túlmenően a molekulaszerkezet is befolyással van a biodegradáció sebességére. Ezért a különböző szerkezettel és xenofor csoportokkal rendelkező gyógyszermolekulák azonos kezelési idő alatt eltérő mértékben degradálódnak. Irodalmi adatok szerint a fent említett négy fájdalomcsillapító és gyulladásgátló koncentrációja a hagyományos technológiával üzemelő szenny víztisztítók kifolyóinál $0,05-5 \mu \mathrm{g} / \mathrm{L}$ közötti tartományban változik.

A szennyvíztisztítóknak a felszíni vizeink vízminőségére gyakorolt hatása szempontjából azonban figyelembe kell venni a befogadó felszíni víz vízhozamát. Például a Duna esetében, melynek átlagos vízhozama $2350 \mathrm{~m}^{3} / \mathrm{s}$, közel ötszázszo- 
ros hígítási faktorral számolhatunk, ha a napi szennyvízkibocsátás Budapesten mintegy $400000 \mathrm{~m}^{3}$. Ez a hígítás jelentős szerepet játszik a vízi ökológiai rendszer szempontjából. Ugyanakkor hangsúlyozni kell azt a tényt is, hogy a ng/L koncentráció tartományban jelen lévő szerves mikroszennyezők jelentős dúsulása tapasztalható a Duna medrében lévő alzatokon kialakult biofilmekben (Dobor et al., 2012). Ez utóbbiak viszont a tápláléklánc egyik elemét jelentik a vízi ökológiai rendszerben. Megemlítendő az a tény is, hogy a Duna partján fekvő szennyvíztisztítókkal szemben számos hazai település szennyvíztisztítóinál befogadóként csak kis vízhozamú folyók vagy patakok állnak rendelkezésre, így a biológiai úton tisztított szennyvíznek csak csekély mértékü hígításával számolhatunk, és megnő a szerves mikroszennyezők talajvízbe jutásának valószínűsége.

Következő lépésként az ELTE KKKK munkatársai a szteroidok, köztük az EU megfigyelési listára azóta felvett ß-ösztradiol (E2) és az etinil-ösztradiol (EE2) meghatározására dolgoztak ki származékképzéssel kapcsolt GC-MS/MS-módszert (Andrási et al., 2011, 2013). A Duna budapesti szakaszán 2011-12-ben vett vízminták oldatfázisában az E2 és az EE2 koncentrációja $<0,2-0,7$, illetve $<0,2-$ $1,2 \mathrm{ng} / \mathrm{L}$ tartományban változott. Ezen két hormon vízmátrixból történő meghatározásához az MTA Ökológiai Kutatóközpont Balatoni Limnológiai Intézete és a Pécsi Tudományegyetem kutatói a célmolekulák elválasztását és dúsítását szintén SPE-technikával oldották meg, majd származékképzést követően folyadékkromatográf-tömegspektrométer rendszert (LC-MS/MS) alkalmaztak a kvantitatív vizsgálatokhoz. Módszerük felhasználásával hét folyóból (Duna, Tisza, Dráva, Száva, Mura, Zala, Zagyva) és több kisebb vízfolyásból, valamint a Balatonból vett huszonhárom vízminta analízisét végezték el egy kampány során. Az ELTE kutatói által mért dunai adatokhoz nagyságrendileg hasonló eredményeket kaptak, azonban az E2 és az EE2 koncentrációja a különböző víztestekből származó vízminták oldatfázisában $<0,05-7,3$, illetve $<0,001-0,7$ ng/L között változott. Ezen adatok természetesen csak jelzésértéküek, hiszen a Duna esetében is eltérö időpontokban és helyeken vett minták eltérő módszerekkel végzett mérésein alapulnak. Tehát az eddig publikált eredmények születését csak a kutatói kíváncsiság iniciálta, és nem volt mögötte szervezett és rendszeres mintavételi kampány, illetve analitikai kémiai tevékenység az idevonatkozó hazai helyzet feltárására.

Pozitív elörelépést jelentett, hogy az EU vízminőség monitorálási programjának megfelelően a diklofenák és a fent említett két hormon, valamint a megfigyelési listára újonnan felvett három, makrolid típusú antibiotikum (eritromicin, klaritromicin, azitromicin) koncentrációjának mérését 2016-tól évente két alkalommal a Pest és a Győr-Moson-Sopron Megyei Kormányhivatal laboratóriumai egységesen elöírt SPE-LC-MS/MS-módszerrel elvégzik. Ezen vizsgálatok az alábbi helyszíneken vett vízminták vizsgálatára irányulnak: a Duna Budapest alatti szakasza, a Zagyva (Újszász), a Hortobágy-Berettyó (Mezőtúr), a Tócó (Mikepércs) és a Kenyérmezei-patak (Dorog). Adataik szerint az E2 és EE2 kon- 
centrációja mind az öt vízfolyás esetében kisebb volt az alkalmazott analitikai módszer mennyiségi kimutatási határánál $(0,4 \mathrm{ng} / \mathrm{L})$. Hasonló a helyzet a három makrolid típusú antibiotikumnál, ahol a 90 ng/L meghatározási határt ezen antibiotikumok koncentrációja csak a Tócó-patakban haladta meg. Ezzel szemben a diklofenák koncentrációja 10 és 3250 ng/L között változott, de a kiugróan magas értéket ebben az esetben is a Tócó-patak vizében regisztráltak.

A kutatók és vízügyi szakemberek egy része legyint, látva ezeket az adatokat, miszerint a ng/L koncentrációban jelen lévő szennyezők biológiai hatása elhanyagolható, és nem jelentenek humán vagy állategészségügyi kockázatot, továbbá nem veszélyeztetik a vízi ökológiai rendszer egyensúlyát. Ezen szemlélettel szemben azonban fel kell tenni a kérdést, hogy a jelenlegi ismereteink elegendők-e a többféle szerves mikroszennyező együttes és hosszú távú hatásának megítéléséhez és az esetleges kockázat felvállalásához. Svájci és német kutatók, valamint vízügyi szakemberek azon a véleményen vannak, hogy ezen bizonytalan helyzetet kiküszöbölendő, feltétlenül szükséges a szerves mikroszennyezők, így a gyógyszermaradványok, illetve metabolitjaik eltávolítása a szennyvíztisztítás során. 2015 szeptemberében a svájci Herisau településen, majd 2016-ban a bajorországi Ulm városában üzembe helyezték azon négyfokozatú szennyvíztisztító üzemeket, amelyeknél aktívszenet alkalmazó, adszorpciós technológiával eltávolítják az említett szerves mikroszennyezők mintegy 80\%-át. Ez kétségtelenül költségnövelést eredményez, de csökkenti az ismeretlen hosszú távú hatás kockázatát.

Várható trendek és ezekből fakadó teendőink:

Teendőink megfogalmazásánál és infrastruktúra-fejlesztéseinknél az alábbi tények figyelembevétele ajánlott:

- A Föld lakosságának száma és átlagéletkora folyamatosan emelkedik, ami együtt jár a gyógyszerfogyasztás várható növekedésével. Természetesen jelentős különbségek vannak e két tényező tekintetében a fejlett vagy gazdaságilag elmaradottabb országok között, de a folyók nem ismernek határokat.

- A klímaváltozással együtt járó hőmérséklet-növekedés következtében várhatóan csökken a befogadóként szolgáló vízfolyások vízhozama, és ennek következtében nő a felszíni vizekben a gyógyszermaradványok koncentrációja.

- A gyógyszertervezés és -gyártás szereplőitől a közeljövőben nem várható, hogy a kívánt biológiai hatás elérése mellett rövid időn belül célul tüzzék ki a különböző hatóanyagoknak a szennyvíztisztítás során alapvető szerepet játszó biológiai lebonthatóság kérdését is, azaz a green pharmacy ezen értelmü megjelenésére még várnunk kell.

Miközben felelősek vagyunk a parti szürésű kutakból származó ivóvizeink minőségéért és ivóvízbázisaink védelméért, a vízi ökológiai rendszer egyensúlyának megtartásáért, nem szabad figyelmen kívül hagyni a fentiekben említett jelenségeket és trendeket. Ezért a Svájcban és Németországban megkezdett úton kellene 
nekünk is haladni, azaz a jelenleg alkalmazott, a szennyezöknek elsődlegesen biológiai úton történő lebontásán, eltávolításán alapuló szennyvíztisztítási technológiát ki kell egészítenünk egy, a nehezen lebontható szerves mikroszennyezők eltávolítását célzó lépcsővel.

\section{IRODALOM}

Andrási N. - Helenkár A. - Záray Gy. et al. (2011): Derivatization and Fragmentation Pattern Analysis of Natural and Synthetic Steroids, as Their Trimethylsilyl (Oxime) Ether Derivatives by Gas Chromatography Mass Spectrometry: Analysis of Dissolved Steroids in Wastewater Samples. Journal of Chromatography A, 1218, 14, 1878-1890. DOI: 10.1016/j.chroma.2011.01.051, https://bit.ly/2LsHdgM

Andrási N. - Molnár B. - Dobos B. et al. (2013): Determination of Steroids in the Dissolved and in the Suspended Phases of Wastewater and Danube River Samples by Gas Chromatography, Tandem Mass Spectrometry. TALANTA, 115, 1, 367-373. DOI: 10.1016/j.talanta.2013.05.029

Avar P. - Zrinyi Z. - Maász G. et al. (2016): $\beta$-estradiol and Ethinyl-estradiol Contamination in the Rivers of the Carpathian Basin. Environmental Science and Pollution Research, 23, 11630-11638. DOI: 10.1007/s11356-016-6276-2, http://real.mtak.hu/43118/1/AvarP_etal_PirgerZ_ESPR_ms.pdf

Dobor J. - Varga M. - Záray Gy. (2012): Biofilm Controlled Sorption of Selected Acidic Drugs on River Sediments Characterized by Different Organic Carbon Content. Chemosphere, 87, 105-110. DOI: 10.1016/j.chemosphere.2011.11.067, https://bit.ly/2zO8Yvo

Istvánovits V. (2015): Felszíni vizek kutatása Magyarországon - helyzetkép és javaslatok. Magyar Tudomány, 176, 7, 843. http://www.matud.iif.hu/2015/07/15.htm

Jones, O. A. - Lester, J. N. - Voulvoulis, N. (2005): Pharmaceuticals: A Threat to Drinking Water? Trends in Biotechnology, 23, 163-167. DOI: 10.1016/j.tibtech.2005.02.001, https://www.researchgate.net/publication/7953788 Pharmaceuticals_A Threat to Drinking Water

Kümmerer K. (ed.) (2001): Pharmaceuticals in the Environment. Berlin-Heidelberg: Springer-Verlag

Sebők A. - Sezer, K. -Vasanits-Zsigrai A. et al. (2008): Gas Chromatography-mass Spectrometry of the Trimethylsilyl (Oxime) Ether/Ester Derivatives of Cholic Acids: Their Presence in the Aquatic Environment Journal of Chromatography A, 1211, 104-112. DOI: 10.1016/j.chroma.2008.09.079, https://bit.ly/2LlbVrX

Sebők A. - Vasanits-Zsigrai A. - Helenkár A. et al. (2009): Multiresidue Analysis of Pollutants as Their Trimethylsilyl Derivatives, by Gas Chromatography-mass Spectrometry. Journal of Chromatography A, 1216, 2288-2301. DOI: 10.1016/j.chroma.2009.01.056, https://bit.ly/2zSMPfn 